http://dx.doi.org/10.11646/phytotaxa.127.1.18

\title{
A review of past and recent research on Cretaceous silicoflagellates
}

\author{
KEVIN McCARTNEY ${ }^{1}$ \\ ${ }^{I}$ Department of Environmental Studies, University of Maine at Presque Isle, Presque Isle, ME 04769, USA \\ Email: kevin.mccartney@umpi.edu (corresponding author)
}

\begin{abstract}
Previous knowledge of Cretaceous silicoflagellates has come primarily from scattered Maastrichtian or late Campanian localities. Silicoflagellates from the earlier Upper Cretaceous have been observed from the southern shore of the Baltic Sea and eastern slope of the northern Ural Mountains, and Lower Cretaceous from the Weddell Sea near Antarctica are also known. Much of the previous work, including type specimens for genera and species, have been illustrated with few and simple line drawings. Taxonomic distinctions and evolutionary lineages have often been speculative.

Recent studies of Santonian and lower Campanian marine sediments from several sites in the northern Canada Arctic Margin and Archipelago substantially increase our knowledge of Cretaceous silicoflagellate morphology, biostratigraphy, and early evolutionary history. This work, which develops from previous diatom studies, provides new information on the enigmatic genera Cornua and Variramus, describes new genera and species, and presents new information on the timing of silicoflagellate evolutionary events. Seven new biostratigraphic zones replace the previously applied single biostratigraphic unit for the Cretaceous.

This article reviews recent silicoflagellate discoveries in the context of previous work to provide a current general knowledge of the subject that includes important taxa.
\end{abstract}

\section{Introduction}

Silicoflagellates are single-celled heterokont algae with certain haptophyte affinities (Daugbjerg \& Henriksen 2001). They are photosynthetic, exclusively marine, and in life are generally restricted to the euphotic zone. Silicoflagellates are well understood and are used biostratigraphically in the Neogene though general utility is less than that of diatoms or radiolarians due to sparser evolutionary events. Their skeletons are composed of opal-A material that becomes unstable upon deeper burial (Littke et al. 1991), which reduces preservation potential in Paleogene and Cretaceous sediments.

Silicoflagellates have an extensive and fairly well studied Cenozoic record with high and low-latitude zonations for most of the era (see Perch-Nielsen 1985). Cenozoic skeletons consistently have a basal ring of generally polygonal shape and constructed of more or less linear sides, that meet to form corners. Most also have an apical structure built upon struts that attach one to each basal side. The apical structure and basal ring give a general hemispherical shape to the skeleton. There are typically spines at the corners of the basal ring and each side has a pike that points away from the apical structure (abapically).

The known silicoflagellate record begins in the Cretaceous, but the early history has not been well understood. Until recently, this record consisted of six genera, one of which was problematic, and a single formally described biostratigraphic zone. That zone and most known Cretaceous silicoflagellate taxa are from the latest Campanian to Maastrichtian. Rare and isolated occurrences of older silicoflagellates were separated by extensive time intervals where silicoflagellates had not been observed or studied.

Recently studied sediments have provided silicoflagellates within these previous gaps and new interpretations of Cretaceous evolutionary history. These discoveries include new taxa and an improved understanding of the history and diversity for all six previously known and two new genera. The number of 
biostratigraphic zones has increased to seven. These provide an opportunity to reexamine the known Cretaceous record in light of the new observations.

\section{Initial studies of Cretaceous silicoflagellates}

Silicoflagellates were first described by C. G. Ehrenberg in the late 1830s. Ehrenberg wrote some 20 papers on them, for which he erected the genus Dictyocha Ehrenberg (1837: 61). Among the various species was Dictyocha triacantha (Ehrenberg 1844: 80), which had three basal sides. The first to recognize the silicoflagellates as a separate group was Lemmermann (1901), who described many new varieties of $D$. triacantha that are now recognized as separate species. Lemmerman's two pages of figures consisted of simple line drawings with usually one illustration per new variety.

Cretaceous silicoflagellates were not discovered until 1928, when both Hanna and Schulz published landmark papers. Hanna (1928) observed diverse silicoflagellates from the Moreno Shale of southern California. He placed the three-sided skeletons into the new genus Corbisema Hanna (1928: 261), and described the new species C. geometrica Hanna (1928: 261)(Fig. 1), which usually had an apical plate. This genus, including $C$. geometrica, is also important in the Paleogene, which accounts for their previous illustration by Ehrenberg and Lemmermann from Cenozoic sediments.

In addition to Corbisema, Hanna (1928) described a four-sided silicoflagellate skeleton as Dictyocha quadralta Hanna (1928: 261)(Fig. 2), and the genera Vallacerta Hanna (1928: 262)(Fig. 3) and Lyramula Hanna (1928: 262)(Figs. 4-5), neither of which had been previously illustrated. The genus Vallacerta has an apical dome that is connected directly to the basal ring without the occurrence of struts. Illustrated pecimens of $V$. hortonii Hanna (1928: 262) had five basal sides. Lyramula has a simple 'Y,' V,' or 'U'-shaped skeleton made of two curved limbs that meet at an angle, perhaps with a spine.

Schulz (1928) was published a few months after Hanna's paper and without prior knowledge of this work. Schulz examined sponge "mummies" that wash out of a cliff on the then-German coast near what is now Gdynia in Poland, and observed well-preserved silicoflagellates. The mummies were deposited as glacial outwash and their geographic origin is unknown. Schulz observed both Corbisema and Vallacerta, which he retained in the genus Dictyocha, but described the new genus and species Cornua trifurcata Schulz (1928: 285), which has three struts whose terminations bifurcate into basal elements that do not connect to form a basal ring (Fig. 6). Schulz illustrated three skeletons of Cornua from abapical and oblique view that show linear basal elements and prominent pikes.

Deflandre (1940, 1944, 1950) obtained a sample from Hanna labeled as "Diatomite de Panoche Hills, Fresno County, Cal. (Etage de Moreno)," that included a variable group of silicoflagellate skeletons that lacked basal rings, which he described as Cornua aculeifera Deflandre (1944: 464)(Fig. 7) and illustrated with three line drawings. Deflandre emphasized that the skeletons were remarkably plastic, and that it was difficult to find two specimens that were alike. Also described was Vallacerta hannai Deflandre (1944: 463), which had small skeletons with seven basal sides and pikes that occurred on struts at some distance from the base of an apical plate.

Jousé $(1949,1951)$ and Gleser (1959) observed Cretaceous silicoflagellates at various localities on the eastern slope of the northern Ural Mountains. The silicoflagellates observed by Jousé are probably from the early Campanian; those of Gleser are probably older and may age into the Santonian. Gleser (1959) identified Cornua aculeifera, C. trifurcata and described the new species C. poretzkajae Gleser (1959: 110)(Fig. 8), illustrating each with a single line drawing, though a few more illustrations were provided in Gleser (1966), translated into English in 1970. C. poretzkajae has basal elements that bend towards the basal element of the next adjacent strut and takes the general appearance of a Corbisema that is missing the corners. Gleser (1959) also described Vallacerta tumidula Gleser (1959: 107), whose apical dome has a central area separated from the rest of the dome by an incised trench. 

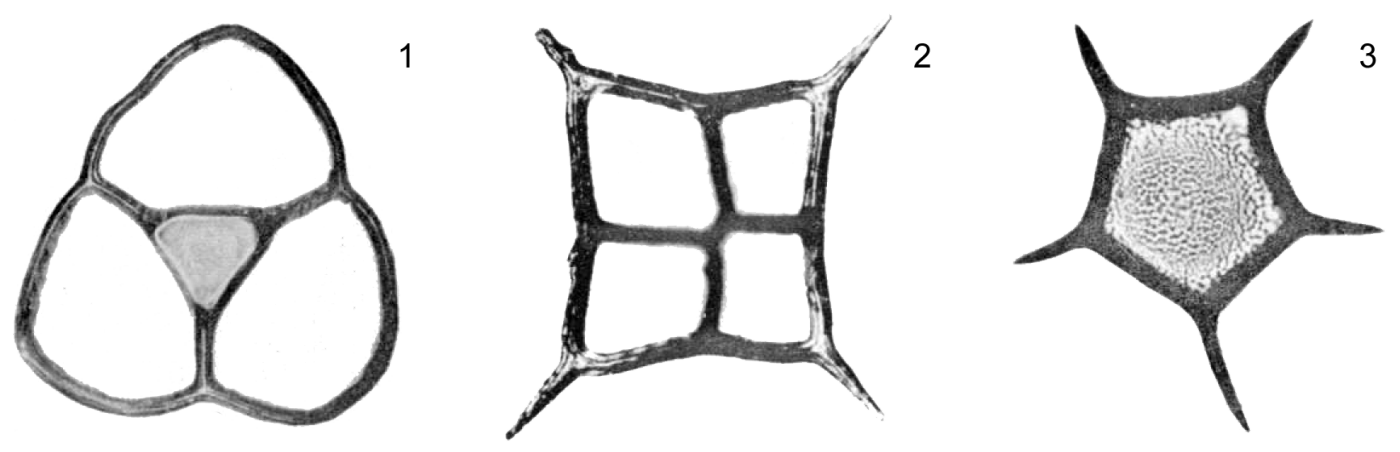

(1)
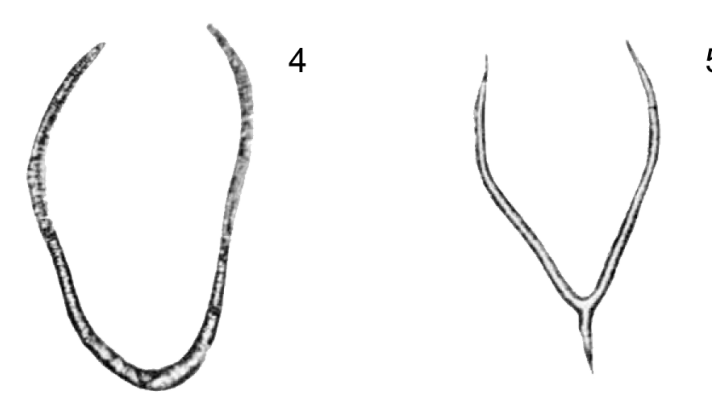

5

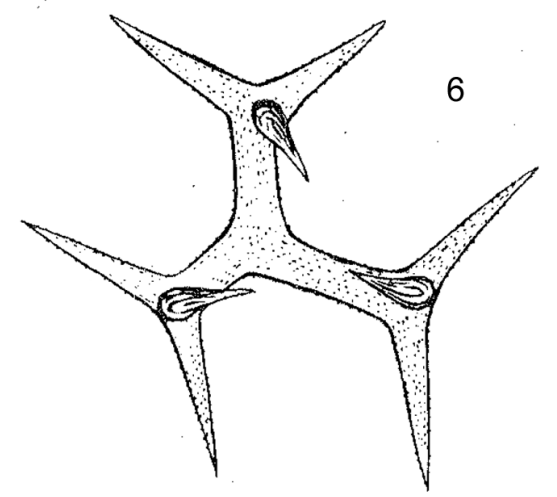

7

8
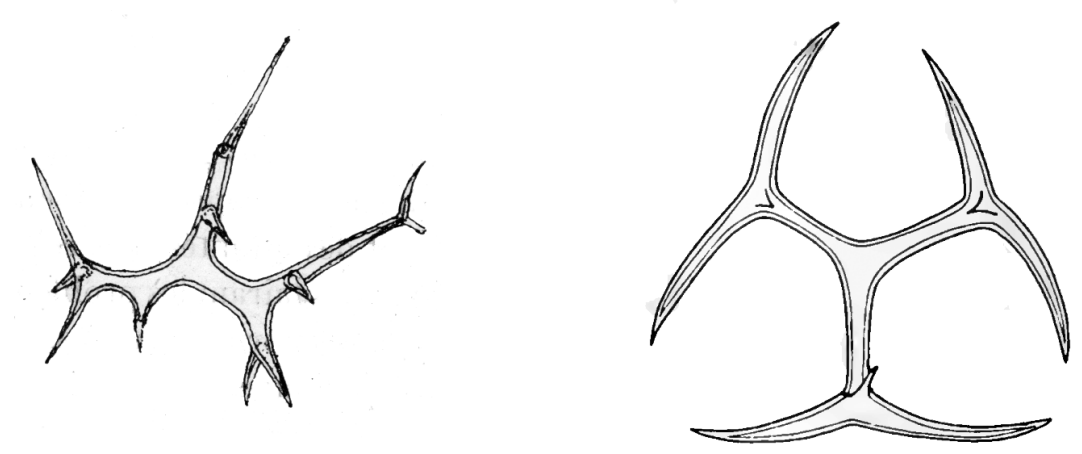

FIGURES 1-8: Original illustrations for important silicoflagellate taxa to 1959. Fig. 1. Corbisema geometrica, Hanna (1928). Fig. 2. Dictyocha quadralta Hanna (1928); placed in Arctyocha by Bukry (1985). Fig. 3. Vallacerta hortoni Hanna (1928); now usually called V. hortonii. Fig. 4. Lyramula simplex Hanna (1928). Fig. 5. Lyramula furcula Hanna (1928). Fig. 6. Cornua trifurcata Schulz (1928). Fig. 7. Cornua aculeifera Deflandre (1944); placed in Variramus by McCartney et al. (1990). Fig. 8. Cornua poretzkajae Glezer (1959).

The Cretaceous silicoflagellate literature summarized to this point represents the initial articles on the subject, which describe four genera - Corbisema, Lyramula, Vallacerta and Cornua. Except for Hanna (1928), all the silicoflagellates presented to here were illustrated with simple line drawings. Mandra (1960, 1968), Tsumura (1962), Ling (1972) and Cornell (1974) further examined silicoflagellates from the Moreno formation of California and have separated Corbisema into various species, often elevating to species level the varieties originally described by Lemmermann (1901).

More recent silicoflagellate study during the remainder of the $20^{\text {th }}$ century can be quickly presented, as there are few significant papers that introduce important new taxa. Bukry (1985) noted that skeletons of Dictyocha quadralta Hanna (1928: 261) lack basal pikes and are not evolutionarily related to Cenozoic Dictyocha and placed this taxon in the new genus Arctyocha Bukry (1985: 130). This skeletal morphology had also been observed in the Moreno Shale (Mandra 1960, 1968), Deep Sea Drilling Project (DSDP) Leg 29 Site 275 of the Southwest Pacific (Perch-Nielsen, 1975) and the CESAR-6 core from the Arctic Ocean (Ling et al. 1973, Bukry 1981, Dell'Agnese \& Clark 1994). 
Silicoflagellates from the Lower Cretaceous were observed by McCartney et al. (1990), who describe a Lower Cretaceous, Albian age, flora that occur in a short interval of Ocean Drilling Program (ODP) Leg 113 Site 693 of the Weddell Sea near Antarctica. The silicoflagellate flora consisted of small seven-sided Vallacerta hannai very similar to those of Deflandre (1944) and an extremely variable group similar to Cornua aculeifera illustrated in the same paper. The new genus Variramus McCartney, Wise, Harwood \& Gersonde (1990: 432) included most of the morphological variation into $V$. aculeifera (Deflandre) McCartney, Wise, Harwood \& Gersonde (1990: 432), with quadrate skeletons placed in the new species $V$. loperi McCartney, Wise, Harwood \& Gersonde (1990: 432).

Of the six Cretaceous genera presented thus far, Cоrnua was particularly enigmatic as the few illustrations provided little detail and information was scanty. While Cornua had been reported in a few studies (Bukry 1974, Quinterno et al. 1994, Desikachary \& Prema 1996) since the work of Gleser, these were present in very low numbers and not accompanied by good photographs; it is uncertain that any of these later occurrences are actually Cornua. Lipps (1970), in a review article, believed that the illustrated Cornua might be sponge spicules while McCartney (1987) thought that they could be teratoid Corbisema.

The three periods of time where silicoflagellates had been observed and studied - the Maastrichtian, Santonianlearly Campanian and Aptian - are separated by two lengthy time intervals. The youngest of these intervals includes most of the Campanian. While the precise stratigraphic position of the Schulz (1928) and Gleser (1959) studies are unknown, these probably straddle the Santonian and earliest Campanian. Some of the later Cretaceous studies, especially those where Arctyocha are present, include the latest Campanian. Most of the Campanian, which spanned about $13 \mathrm{myr}$, had not been examined for silicoflagellates. The second and more lengthy gap in the known silicoflagellate record extends from the Albian to Santonian, or about 25 myr.

\section{Recent discoveries}

Recent work on sediments from northern Canada provides information from these previously unstudied intervals. These discoveries develop from two Masters theses that investigated diatom history during the Santonian and Campanian. Tapia (1996) and Tapia \& Harwood (2002) examined sediments from the Horton River near the northern coast of Canada and several islands of the Canadian Archipelago, while Witkowski (2008), Chin et al. (2008) and Witkowski et al. (2011) studied sediments from Devon Island in the Canadian High Arctic. These sediments have extraordinarily well preserved silicoflagellates of unusual skeletal morphologies, and include the first Cornua trifurcata to be photographed (Fig. 9).

The Horton River site spans nearly the entire Campanian. The highest portion of this sequence contains a flora consistent with the Lyramula furcula Zone described by Bukry \& Foster (1974), which was previously the only silicoflagellate zone of the Cretaceous. Near the bottom of this sequence are sediments that contain abundant Cornua trifurcata, which are used to define the C. trifurcata Partial Range Zone (McCartney et al. 2011a). The top of this zone is defined as the last abundant - and probable extinction - of the nominative taxon. Immediately above the C. trifurcata Zone is a depauperate interval that lacks Cornua, described as the Lyramula minor Interval Zone, characterized by a predominance of Lyramula minor (Deflandre) Deflandre (1950: 62). The general small size of the silicoflagellates and unusual morphologies of both Lyramula and Corbisema suggest that this zone may represent an environmentally stressed interval of time that followed the extinction of much of the previous silicoflagellate flora (McCartney et al. 2011a).

Above the Lyramula minor Interval Zone are two zones named after species of Arctyocha. The oldest of these is the Arctyocha mesocena Range Zone, which has abundant specimens of two new Arctyocha species: A. balkwillii McCartney, Witkowski \& Harwood (2011a: 68) has basal rings with six to twelve or more sides and a wide range of apical designs while A. mesocena McCartney, Witkowski \& Harwood (2011a: 69) lacks an apical structure (Fig. 10). Above this zone is the A. quadralta Range Zone; the other Late Cretaceous occurrences that have common A. quadralta, in California, the CESAR-6 core and DSDP Site 275, may correlate with this interval. 

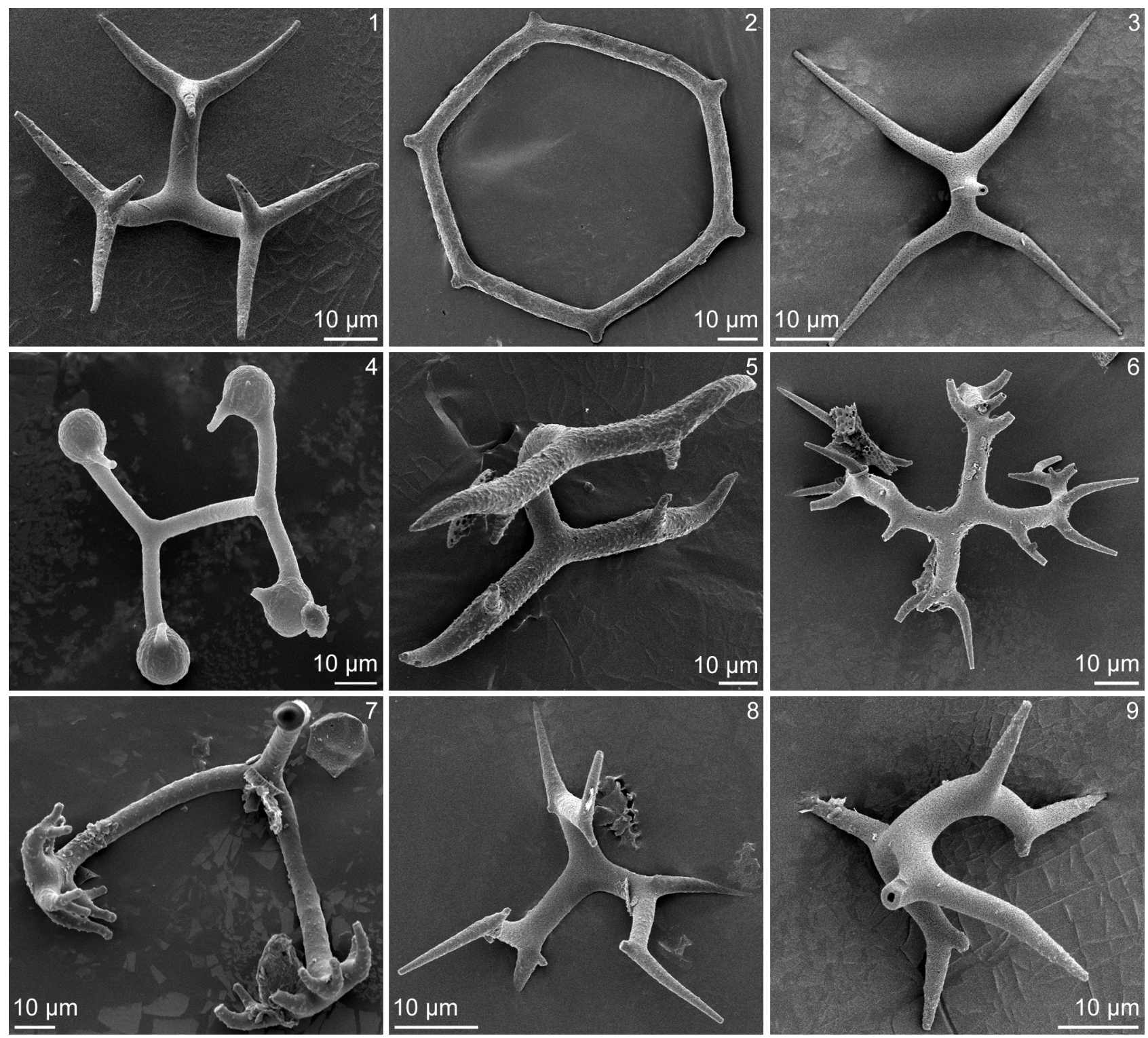

FIGURES 9-16: Recently discovered or photographed Cretaceous silicoflagellates. Fig. 9. Modern photograph of Cornua trifurcata, Til'tim XI locality (see Witkowski et al, 2012). Fig. 10. Arctyocha mesocena, sample C-8606, Horton River, Canada. Fig. 11. Schulzyocha loperi, ODP 113-693B-19X-4, 77-78 cm. Fig. 12. Schulzyocha ruppelii, EF0103, Devon Island, Canada. Fig. 13. Schulzyocha lurveyi, EF0102, Devon Island, Canada. Fig. 14. Umpiocha umpiana, EF0401, Devon Island, Canada. Fig. 15. Umpiocha jeletskyi EF0401, Devon Island, Canada. Fig. 16. Umpiocha jeletzskyi, EF0401, Devon Island, Canada. Fig. 17. Cornua tapiae, EF0401, Devon Island, Canada. Variramus wisei, ODP 113-693B-19X-4, 77-78 cm.

The Arctyocha mesocena Zone also shows an evolutionary transition for Corbisema lateradiata (Schulz) Perch-Nielsen (1975: 686) through C. geometrica Hanna (1928: 261) to C. parallela Hajós \& Stradner (1975: 938), which is a trend to larger and rounder basal rings and apical plates. These skeletal morphologies were previously known in the Maastrichtian, without knowledge as to which was the more primitive. Deflandre (1940) thought that $C$. geometrica was as long-lived species that through expansion of the apical plates had given rise to Vallacerta. The Horton interval showed that $C$. geometrica was a later development from a more trigonal basal ring with pointed corners. All three corbisemid morphologies continue into the Paleogene.

The Devon Island interval is interpreted as Santonian to early Campanian in age and contains well preserved silicoflagellates of three assemblages, each described as a zone (McCartney et al. 2011b). The youngest of these is the Cornua trifurcata Zone described in McCartney et al. (2011a). Below this zone are two assemblages of very unusual and previously undescribed silicoflagellates. These are the Schulzyocha ruppelii Range Zone and below that the Vallacerta tumidula Partial Range Zone. 
The Schulzyocha ruppelii Range Zone is characterized by the occurrence of several species of the new genus Schulzyocha (McCartney et al. 2011b: 50). The type species of this genus is S. loperi (McCartney, Wise, Harwood \& Gersonde) McCartney, Witkowski \& Harwood (2011b: 51)(Fig. 11), described by McCartney et al. (1990) as a species of Variramus. The nominative species of the zone is Schulzyocha ruppelii McCartney, Witkowski \& Harwood (2011b: 52), an extremely unusual silicoflagellate with bulbs (Fig. 12) at the ends of the struts. The zone includes five new species of this genus, including $S$. lurveyi McCartney, Witkowski \& Harwood (2011b: 51)(Fig. 13), which has very unusual basal elements. All of the new Schulzyocha species are restricted to the Schulzyocha ruppelii Zone. The Schulzyocha ruppelii Zone also has in its bottommost sample the oldest known occurrence of Lyramula, which does not occur in the underlying zone.

The Vallacerta tumidula Partial Range Zone includes a variety of especially unusual taxa, even by the standards established by the Schulzyocha ruppelii Zone. The most unusual of these is the new genus Umpiocha McCartney, Witkowski \& Harwood (2011b: 52), which is characterized by long limbs that curve beneath the apical structure, with terminations that come near to touching. The four curved limbs are not connected to an obvious basal plane, with a general shape that is more spherical than all known silicoflagellates except the Neogene Cannopilus Haeckel (1887: 1567). Two species have been placed in Umpiocha; U. umpiana McCartney, Witkowski \& Harwood (2011b: 53)(Fig. 14) has two rows of spines on the limbs while U. jeletskyi McCartney, Witkowski \& Harwood (2011b: 53)(Fig. 15) lacks spines but has digitated terminations to the limbs.

The Vallacerta tumidula Partial Range Zone also includes an unusual new species of Cornua. The struts of C. tapiae McCartney, Witkowski \& Harwood (2011b: 49)(Fig. 16) terminate in basal elements that are twisted and do not occur in a planar surface as do the basal elements of previously described Cornua. A similar twist is repeated at the end of each strut, producing a "pinwheel" effect. The Cornua have considerable variability and has been observed during recent reexamination of the ODP Site 693 material (McCartney et al. 2011a), making this and Variramus wisei McCartney, Witkowski \& Harwood (2011b: 55)(Fig. 17) especially long-lived Cretaceous silicoflagellate species.

\section{Discussion}

The silicoflagellate literature is briefly summarized in Table 1. Both the Horton River and Devon Island floras provide a broader context for interpreting silicoflagellates of the Cretaceous. The base of the Horton River section provides the first Cornua trifurcata assemblage observed in half a century, and the first ever to be extensively documented photographically. This, combined with the older flora of Devon Island and ODP Site 693, represents an archaic group of silicoflagellates of which only Vallacerta has a basal ring. The other archaic genera are Variramus, Cornua, Schulzyocha and Umpiocha, all of which lack a basal ring.

With the exception of Vallacerta, this archaic silicoflagellate flora either becomes extinct or very much less abundant at the top of the C. trifurcata Zone, in the early Campanian. The overlying Lyramula minor Zone has a depauperate flora dominated by small and unusual Lyramula. If this zone does represent recovery following a silicoflagellate mass extinction, the recovery was rapid as the zone occurs in only a single sample in the Horten River section. Rapid diversification followed with the evolution of Arctyocha and appearance of plated Corbisema in the next higher zone.

Arctyocha and Corbisema, combined with Lyramula and Vallacerta, form the late Campanian/ Maastrichtian flora that has been the subject of most of Cretaceus silicoflagellate literature. The previous literature, however, does not discuss the many-sided Arctyocha and the diverse morphologies that lack an apical structure observed in the Horton River section. This record shows a trend for Arctyocha towards fewer basal sides and less complex apical structures as the Campanian proceeds. Four-sided Arctyocha morphologies are most typical near the Campanian/Maastrichtian boundary. It is uncertain if and for how long the genus persists into the Maastrichtian, but it is generally not present in exclusively Maastrichtian sections. 
At about the time that Arctyocha diminishes in abundance, more complex Lyramula morphologies with three to many limbs and less symmetrical skeletons occur. Complex Lyramula skeletons were illustrated by Deflandre $(1940,1950)$ and also observed in section 2-5 of DSDP Site 275 (Bukry 1975) and the CESAR-6 core (Bukry 1981). Unusual Arctyocha morphologies that have struts that support an apical window have also been observed in the late Campanian (Harwood 1988, McCartney et al. 2010b). A detailed examination of the California and Site 275 sections is needed to determine if these transitions are correlated with other evidence of environmental stress.

Despite the many papers that include observations of silicoflagellates in the Maastrichtian, few generalizations can be made about the nature of that record. No near complete record of Maastrichtian silicoflagellate history is available, as can be observed at Horton River for the Campanian. Except for the section at Seymour Island (Harwood 1988), little information is available about the impact of the terminal Cretaceous extinction event on the silicoflagellates. If any of the Cretaceous silicoflagellate genera except Corbisema survived the K\Pg boundary, they did not persist for long. All Cenozoic silicoflagellates evolved from Corbisema.

TABLE 1: List of all Cretaceous silicoflagellate literature, with age and geographic region. "X?" indicates where the taxon was identified but the authors of the reference maintain some level of uncertainy as to its identification, "?" indicates where the authors think this taxon may occur.

\begin{tabular}{|c|c|c|c|c|c|c|c|c|c|c|}
\hline Reference & Age & Geographic Region & 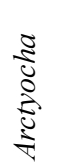 & 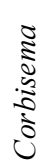 & ن̃ & 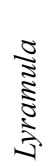 & 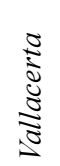 & 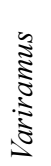 & & 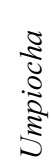 \\
\hline Bukry, 1974 & Maastrichtian & DSDP Site 216, E Indian Ocean & & $\mathrm{X}$ & $\mathrm{X}$ ? & $\mathrm{X}$ & $\mathrm{X}$ & & & \\
\hline Bukry, 1975 & late Campanian-Maas. & DSDP Site 275, SW Pacific Ocean & $\mathrm{X}$ & $\mathrm{X}$ & $\mathrm{X} ?$ & $\mathrm{X}$ & $\mathrm{X}$ & $?$ & & \\
\hline Bukry, 1981, 1985 & late Campanian-Maas. & Alpha Ridge, Arctic Ocean & $\mathrm{X}$ & $\mathrm{X}$ & $?$ & $\mathrm{X}$ & $\mathrm{X}$ & $?$ & $?$ & \\
\hline Cornell, 1974 & Maastrichtian & California, USA & & $\mathrm{X}$ & & & & & & \\
\hline Dell'Agnese and Clark, 1994 & late Campanian-Maas. & Alpha Ridge, Arctic Ocean & $\mathrm{X}$ & $\mathrm{X}$ & & $\mathrm{X}$ & $\mathrm{X}$ & & & \\
\hline Gresham, 1985 & Maastrichtian & DSDP Site 216, E Indian Ocean & $\mathrm{X} ?$ & $\mathrm{X}$ & & $\mathrm{X}$ & & & & \\
\hline Gleser, 1959, 1966 & Santonian to early Camp. & Ural Mountains, Russia & & $\mathrm{X}$ & $\mathrm{X}$ & $\mathrm{X}$ & $\mathrm{X}$ & & & \\
\hline Jouse, 1949, 1951 & & Ural Mountains, Russia & & $\mathrm{X}$ & & $\mathrm{X}$ & $\mathrm{X}$ & & & \\
\hline Hajos and Stradner, 1975 & late Campanian-Maas. & DSDP Site 275, SW Pacific Ocean & $\mathrm{X}$ & $\mathrm{X}$ & & $\mathrm{X}$ & $\mathrm{X}$ & & & \\
\hline Hanna, 1928 & Maastrichtian & California, USA & $\mathrm{X}$ & $\mathrm{X}$ & & $\mathrm{X}$ & $\mathrm{X}$ & & & \\
\hline Harwood, 1988 & Maastrichtian & Seymour Is., Antarctica & $\mathrm{X}$ & $\mathrm{X}$ & & $\mathrm{X}$ & $\mathrm{X}$ & & & \\
\hline Ling, 1972 & Maastrichtian & California, USA & & $\mathrm{X}$ & & $\mathrm{X}$ & $\mathrm{X}$ & & & \\
\hline Ling et al., 1973 & late Campanian-Maas. & Canadian Arctic & $\mathrm{X}$ & & & $\mathrm{X}$ & $\mathrm{X}$ & & & \\
\hline Mandra, 1960, 1968 & Maastrichtian & California, USA & & $\mathrm{X}$ & & $\mathrm{X}$ & $\mathrm{X}$ & & & \\
\hline Martinez Macciavello, 1987 & late Campanian-Maas. & Seymour Is., Antarctica & & $\mathrm{X}$ & & $\mathrm{X}$ & & & & \\
\hline McCartney et al., 1990 & Albian & ODP Site 693, Weddell Sea & & & & & $\mathrm{X}$ & $\mathrm{X}$ & $\mathrm{X}$ & \\
\hline McCartney et al. 2011a & Campanian & Canadian Arctic & $\mathrm{X}$ & $\mathrm{X}$ & $\mathrm{X}$ & $\mathrm{X}$ & $\mathrm{X}$ & $\mathrm{X}$ & & \\
\hline McCartney et al. 2011b & Santonian to early Camp. & Canadian Arctic & & $\mathrm{X}$ & $\mathrm{X}$ & $\mathrm{X}$ & $\mathrm{X}$ & $\mathrm{X}$ & $\mathrm{X}$ & $\mathrm{X}$ \\
\hline Moshkovitz et al., 1983 & Maastrichtian & Israel & & & & $\mathrm{X}$ & & & & \\
\hline Quinterno et al., 1994 & late Campanian-Maas.? & Tonga Trench, Pacific & & $\mathrm{X}$ & $\mathrm{X}$ & $\mathrm{X}$ & $\mathrm{X}$ & $\mathrm{X}$ ? & & \\
\hline Perch-Nielsen, 1975 & late Campanian-Maas. & DSDP Site 275, SW Pacific Ocean & $\mathrm{X}$ & $\mathrm{X}$ & & $\mathrm{X}$ & $\mathrm{X}$ & & & \\
\hline Sawamua and Otowa, 1979 & uncertain & Japan & & & $\mathrm{X}$ & $\mathrm{X}$ & & & & \\
\hline Schulz, 1928 & early Campanian & Baltic Sea, Poland & & $\mathrm{X}$ & $\mathrm{X}$ & & & & & \\
\hline Tsumura, 1963 & Maastrichtian & California, USA & $\mathrm{X}$ ? & & & & $\mathrm{X}$ & $\mathrm{X}$ ? & & \\
\hline
\end{tabular}




\section{Priorities for future study}

The recent discoveries provide a new context for the interpretation of Cretaceous silicoflagellate history. Many of the localities studied in past decades now require new and more detailed examination. Among these is the Moreno formation of California, which has seen little study since Cornell (1974). None of the previous studies were systematic examinations of stratigraphic sections with a high resolution sample interval. The Horton River zonation suggests that the Arctyocha of California may be of latest Campanian age, and not Maastrichtian as generally stated in the Californian silicoflagellate studies.

The presence of unusual Arctyocha and Lyramula near the bottom of core 2 at DSDP Site 275 also needs further study. The Initial Scientific Results for that leg include three silicoflagellates studies (Bukry 1975, Hajós \& Stradner 1975, Perch-Nielsen 1975) which have different species interpretations. Corbisema geometrica v. apiculata Jousé (1951: 78) of Hajós \& Stradner (1975) is equivalent to C. lateradiata (PerchNielsen 1975) and C. geometrica lateradiata (Schulz) Bukry (1975: 853). Such disparities of Corbisema interpretation occur throughout the Maastrichtian literature. There are also differences in the interpretation of Corbisema taxa (C. apiculata Frenguelli (1940: 62), C. inermis (Lemmermann) Bukry (1975: 854), C. archangelskiana (Schulz) Frenguelli (1940: 62)) between the Maastrichtian and Paleogene literature (e.g., McCartney et al. $2011 \mathrm{~b}$, for a discussion of C. inermis). Corbisema requires a thorough study to develop a more consistent species interpretation.

The Devon Island section also deserves much more detailed analysis. The original samples were collected during an exploratory search for fossil vertebrates, so a systematic sampling for microfossil study was not made. The three zones interpreted by McCartney et al. (2011b) were made on the basis of eight samples (three samples for each of the higher two zones, two samples in the lowest zone). Another expedition to this island to obtain more samples would provide a better understanding of the early evolution of Corbisema, as well are the diversification and variability of Cornua and Schulzyocha.

The Devon Island section also provides a better knowledge of Variramus, with three new species which considerably narrow the interpretation of $V$. aculeifera as presented by McCartney et al. (1990). The Albian section of ODP Site 693 needs to be restudied. A reexamination of Site 693 materials has observed Cornua tapiae in the Albian. With the reclassification of V. loperi to Schulzyocha, the known Albian diversity has increased from two Variramus and one Vallacerta species to four genera-Variramus, Vallacerta, Schulzyocha and Cornua - the first of these now having several species.

Work is also needed to determine the provenance of the original sample studied by Deflandre (1940, 1944) from which Vallacerta hannai and what was then called Cornua aculeifera were described. Deflandre obtained this sample from Hanna, who labeled it as Maastrichtian in age, and from a Panoche Hills section of the Moreno formation. Deflandre however described a flora that is very similar to the Albian ODP Site 693 occurrence. If, as appears likely, the locality information was either mislabeled by Hanna or Deflandre, then Where did it come from? Could an unknown Lower Cretaceous silicoflagellate-bearing unit of strata be present in California or elsewhere?

Finally, more work needs to be done on any basic differences between the Cretaceous and Cenozoic silicoflagellate flora. A rare double skeleton of Corbisema was found in the Horton River section and illustrated by McCartney et al. (2010a). This specimen shows each skeleton of the pair rotated with respect to the other, in a "star-of-David" configuration. Double skeleton specimens of Vallacerta and Schulzyocha also show this rotated pattern (McCartney et al. 2010b, 2011b). Thus far, all observed double skeletons from the Cretaceous show rotated double skeletons while Cenozoic double skeletons have the basal corners and spines aligned with each other. Why would Cretaceous and Cenozoic double skeletons be so different? There is still a great deal to learn about the Cretaceous and early Cenozoic silicoflagellate record. 


\section{Conclusions}

During the past century, a variety of workers have observed and illustrated silicoflagellate skeletal morphologies from the Cretaceous. This body of work started with Lemmermann, who in 1901 described Paleogene taxa that are now commonly used for Cretaceous species of Corbisema. Hanna and Schulz in 1928 formally described three additional Cretaceous genera, and illustrated the Cretaceous morphology now known as Arctyocha. Subsequent work through the 1980s have added to the knowledge of these genera through the description of new species and extending their known geographic distributions.

The geologic record of Cretaceous silicoflagellates, however, was not appreciably extended by the subsequent work, as the geologic age of known silicoflagellates continued to be latest Campanian through Maastrichtian, and a relatively brief interval in the Santonian to earliest Campanian. In 1990, the discovery of an assemblage of early and variable silicoflagellates from the Albian extended the known silicoflagellate record considerably, but did not clarify the evolutionary relationships among the previously known genera.

More recent research in the Canadian Arctic provides a better understanding of early silicoflagellates. Cornua is now known to be an important and long-lived genus. The transition from Cornua to Corbisema can now be better placed temporally, and may involve two lineages. An evolutionary lineage is now available for the Corbisema with apical plates. Dates of first appearance are now known for Lyramula and Arctyocha, and unusual new silicoflagellates have been described in the Santonian. This information provides a larger context and new perspective for interpretation of the previously known taxa.

\section{Acknowledgements}

I thank Jakub Witkowski and David M. Harwood for their active involvement in so much of the recent work that has led to a better understanding of Cretaceous silicoflagellates. Jakub Witkowski assisted in the preparation of the figures and provided the SEM photographs.

\section{References}

Bukry, D. (1974) Coccolith and silicoflagellate stratigraphy, eastern Indian Ocean, Deep Sea Drilling Project Leg 22. In: von der Borch, C.C., Sclater, J.G., et al. (Eds.), Initial Reports of the Deep Sea Drilling Project, Scientific Results, U.S. Government Printing Office, Washington, 22: 601-607.

Bukry, D. (1975) Silicoflagellate and coccolith stratigraphy, Deep Sea Drilling Project Leg 29. In: Kennett, J.P., Houtz, R.E., et al. (Eds.), Initial Reports of the Deep Sea Drilling Project, Scientific Results, U.S. Government Printing Office, Washington, 29: 845-872.

Bukry, D. (1981) Cretaceous Arctic silicoflagellates. Geo-Marine Letters 1: 57-63. http://dx.doi.org/10.1007/BF02463303

Bukry, D. (1985) Correlation of late Cretaceous Arctic silicoflagellates from Alpha Ridge. In: Jackson, H.R., Mudie, P.J., Blasco, S.M. (Eds.), Initial Geological Report on CESAR - the Canadian Expedition to Study the Alpha Ridge, Arctic Ocean. Geological Survey of Canada, Paper 84-22: 125-135.

Bukry, D. \& Foster, J.H. (1974) Silicoflagellate zonation of upper Cretaceous to lower Miocene deep sea sediment. Journal Research U.S. Geological Survey 2: 303-310.

Chin, K., Bloch, J.D., Sweet, A.R., Tweet, J.S., Eberle, J.J., Cumbaa, S.L., Witkowski, J. \& Harwood, D.M. (2008) Life in a temperate Polar sea: a unique taphonomic window on the structure of a Late Cretaceous Arctic marine ecosystem. Proceedings of the Royal Society B 275: 2675-2685. http://dx.doi.org/10.1098/rspb.2008.0801

Cornell, W.C. (1974) Maastrichtian silicoflagellates of the Great Valley, California. Geoscience and Man 9: 37-44. http://dx.doi.org/10.1080/00721395.1974.9989747

Daugbjerg N. \& Henriksen, P. (2001) Pigment composition and $r b c$ L sequence data from the silicoflagellate Dictyocha speculum: A heterokont alga with pigments similar to some haplophytes. Journal Phycology 37: 1110-1120. http://dx.doi.org/10.1046/j.1529-8817.2001.01061.x

Deflandre, G. (1940) L'prigine phylogenénétique de Lyramula et l'évolution des Silicoflagellidées. Comptes rendus, 
Académie des Sciences 211: 508-510.

Deflandre, G. (1944) Remarques sur l'évolution des Silicoflagellidées, à propos de deux espèces crétaciques nouvelles. Comptes rendus, Académie des Sciences 219: 463-465.

Deflandre, G. (1950) Contribution à l'étude des Silicoflagellidés actuels et fossils. Microscopie 2: 2-84.

Dell'Agnese, D.F. \& Clark, D.L. (1994) Siliceous microfossils from the warm Late Cretaceous and early Cenozoic Arctic Ocean. Journal Paleontology 68: 31-47.

Desikachary, T.V. \& Prema, P. (1996) Silicoflagellates (Dictyophyceae). Bibliotheca Phycologica, Band 100, 298 p.

Ehrenberg, C.G. (1844) Mittheilung über zwei neue Lager von Gebirgsmassen aus Infusorien als Meeres-Absatz in NordAmerika und eine Vergleichung derselben mit den organischen Kreide-Gebilden in Europa und Afrika. Bericht über die zur Bekanntmachung geeigneten Verhandlungen der Königlich-Preussischen Akademie der Wissenschaften zu Berlin 1844: 57-97.

Frenguelli, J. (1935) Variaciones de Dictyocha fibula en el Golfo de San Matías. Annales del Museo Argentino de Ciencias Naturales 38: 263-381.

Gresham, C.W. (1985) Cretaceous and Paleocene siliceous phytoplankton assemblages from DSDP sites 216,214 and 208 in the Pacific and Indian Oceans. Unpublished Masters Thesis, University of Wisconsin - Madison, 233 p.

Gleser, Z.I. (1959) Nekotorye novye dannye o semeistve Vallacertaceae Deflandre (Silicoflagellatae) (Some new data on the Family Vallacertaceae Deflandre [Silicoflagellatae]). Informatsionnyi Sbornik 10: 103-113.

Gleser, Z.I. (1966) Silicoflagellatophycaea. In: Gollerbakh, M. M. (ed.), Cryptogamic Plants of the S.S.S.R. (Vol. 7). V. A. Komarova Botanical Institute, pp. 363. (Translated from Russian by Israel Program for Scientific Translations Ltd, Jerusalem, 1970.)

Haeckel, E. (1887) Report on the radiolarian collected by H.M.S. Challenger during the years 1873-1876. Report of the Scientific Results of H.M.S. Challenger during the years 1873-1876 18: 1-1803.

Hajós, M. \& Stradner, M. (1975) Late Cretaceous archaeomonads, diatomaceae, and silicoflagellata from the south Pacific Ocean, Deep Sea Drilling Project, Leg 29, Site 275. In: Kennett, J.P., Houtz, R.E., et al. (Eds.), Initial Reports of the Deep Sea Drilling Project, Scientific Results, U.S. Government Printing Office, Washington, 29: 9131010 .

Hanna, G D. (1928) Silicoflagellata from the Cretaceous of California. Journal of Paleontology 1: 259-263.

Harwood, D.M. (1988) Upper Cretaceous and lower Paleocene diatom and silicoflagellate biostratigraphy of Seymour Island, Eastern Antarctic peninsula. In: Feldmann, R., Woodburne, M.D. (eds) Geology and Paleontology of Seymour Island. Geological Society of America Memoir 169: 55-129.

Jousé, A.P. (1949) Novye diatomovye I kremnevye zhgutikovye vodorosli verkhnemelovogo vozrasta iz glinistykh peskov basseina reki Bol'shoi Aktai (vostochnyi sklon Severnogo Urala) (New Diatoms and Silicoflagellates from Upper Cretaceous Argillaceous Sands of the Basin of Bol'shoi Aktai River [Eastern Slope of the Northern Urals]). Botanicheskie Materialy Otdela Sporovykh Rastenii Botanicheskogo Instituta SSSR 6: 65-78.

Jousé, A.P. (1951) Diatomaceae et silicoflaggellatae aetatis supernecretaceae ex arenis argillaceis systematis fluminis Bolschoy Aktay in declivitate oreintali Ural Borealis. Otdela Sporovykh Rastenii, Botanischeskii Institut, Akademia Nauk SSSR 10: 72-76.

Lemmermann, E. (1901) Silicoflagellatae. Deutsche Botanische Gesellschaft, Berichte, 19: 247-271.

Ling, H.-L. (1972) Upper Cretaceous and Cenozoic silicoflagellates and ebridians. Bulletins of American Paleontology, 62(273): 135-229.

Ling, H.-L., McPherson, L.M. \& Clark D.L. (1973) Late Cretaceous (Maastrichtian?) silicoflagellates from the Alpha Cordillera of the Arctic Ocean. Science 180: 1360-1361.

http://dx.doi.org/10.1126/science.180.4093.1360

Lipps, J.H. (1970) Ecology and evolution of silicoflagellates. Proceedings of the North American Paleontologic Convention, Chicago 1969, 2(g): 965-993.

Littke, R., Fourtanier, E., Thurow, J. \& Taylor, E. (1991) Silica diagenesis and its effect on lithification of Broken Ridge deposits, Central Indian Ocean. In: Weissel, J., Pierce, J., et al. (eds) Proceedings of the Ocean Drilling Program, Scientific Results, U. S. Government Printing Office, Washington, 121: 261-272.

Mandra, Y.T. (1960) Fossil silicoflagellates from California, U.S.A. International Geological Congress, XXI Session, Norden, 1960, Report, pt. 6: 77-89.

Mandra, Y.T. (1968) Silicoflagellates from the Cretaceous, Eocene and Miocene of California, U.S.A. California Academy of Science, Proceedings 36: 231-277.

Martinez Macciavello, J. C. M., (1987) Bioestratigrapfia diatomatica de un perfil del Cretacico superior de la Isla Vicecomodoro Marambio, Antarctica. Ameghiniana, 24: 277-288.

McCartney, K. (1987) Silicoflagellates, ebridians and archaeomonads. In: Lipps, J. (ed.) Fossil Procaryotes and Protists: Notes for a Short Course. Paleontological Society and Cushman Foundation, for Geological Society of America Meeting, November, 1987, pp. 146-168.

McCartney, K., Wise, S.W., Jr., Harwood, D.M. \& Gersonde, R. (1990) An enigmatic lower Albian silicoflagellate from ODP Site 693: Progenitors of the Order Silicoflagellata? In: Barker, P. F., Kennett, J. P., et al. (eds) Ocean Drilling 
Program, Scientific Reports 113: 427-442.

McCartney, K., Harwood, D.M. \& Witkowski, J. (2010a) A rare double skeleton of the silicoflagellate Corbisema. Journal of Micropaleontology 29: 185-186. http://dx.doi.org/10.1144/0262-821X09-020

McCartney, K., Witkowski, J. \& Harwood, D.M. (2010b) Early Evolution of the Silicoflagellates during the Cretaceous. Marine Micropaleontology 77: 83-100. http://dx.doi.org/10.1016/j.marmicro.2010.08.001

McCartney, K., Witkowski, J. \& Harwood, D.M. (2011a) Late Cretaceous silicoflagellate taxonomy and biostratigraphy of the Arctic Margin, Northwest Territories, Canada. Micropaleontology 57: 61-86.

McCartney, K., Witkowski, J. \& Harwood, D.M. (2011b) Unusual early assemblages of Upper Cretaceous silicoflagellates from the Canadian Archipelago. Revue de Micropaléontologie 54: 31-58. http://dx.doi.org/10.1016/j.revmic.2010.08.002

Moshkovitz, S., Ehrlich, A. \& Soudry, D. (1983) Siliceous microfossils of the Upper Cretaceous Mishash Formation, central Negev, Israel. Cretaceous Research 4: 173-194. http://dx.doi.org/10.1016/0195-6671(83)90048-4

Perch-Nielsen, K. (1975) Late Cretaceous to Pleistocene silicoflagellates from the southern southwest Pacific, DSDP, Leg 29. In: Kennett, J.P., Houtz, R.E., et al. (eds.) Initial Reports of the Deep Sea Drilling Project, Scientific Results, U.S. Government Printing Office, Washington, 29: 677-721.

Perch-Nielsen, K. (1985) Silicoflagellates. In: Bolli, H.M., Saunders, J.B. and Perch-Nielsen, K. (eds) Plankton Stratigraphy. Cambridge University Press, Cambridge, pp. 811-846.

Quinterno, P.J., Barron, J.A., Bukry, D. \& Blome, C.D. (1994) Late Cretaceous microfossils in a single dredge haul from the Tonga trench: Evidence of late Cretaceous environment at the Louisville Hotspot. In: Stevenson, H.J., Herzer, R.H., Balance, P.F. (eds) Geology and Submarine Resources of the Tonga-Lau-Fiji Region SOPAC Technical Bulletin 8: 285-291.

Sawamura, K. \& Otowa, K. (1979) Silicoflagellates [sic] flora in calcareous concretions found in Cretaceous and Tertiary of Japan. Bulletin Geological Survey of Japan 30: 51-56.

Schulz, P. (1928) Beitrage zur Kenntnis fossiler und rezenter Silicoflagellaten. Botanischen Archiv 21: $225-292$.

Tapia, P.M. (1996) Campanian diatom biostratigraphy and paleoecology of Arctic Canada. Unpublished Master's Thesis, University of Nebraska - Lincoln, 94 pp.

Tapia, P.M. \& Harwood, D.M. (2002) Upper Cretaceous diatom biostratigraphy of the Arctic archipelago and northern continental margin, Canada. Micropaleontology 48: 303-342.

Tsumura, K. (1963) A systematic study of silicoflagellateae. Yokohama Municipal University, Journal C-45, no. 146: 184.

Witkowski, J. (2008) Taxonomy, palaeoecology and biostratigraphic potential of diatoms from the Upper Cretaceous of Devon Island, Canadian High Arctic. Unpublished Master's Thesis, University of Warsaw, 97 pp.

Witkowski, J., Harwood, D.M. \& Chin, K. (2011) Taxonomic composition, paleoecology and biostratigraphy of Late Cretaceous diatoms from Devon Island, Nunavut, Canadian High Arctic. Cretaceous Research 32: $277-300$. http://dx.doi.org/10.1016/j.cretres.2010.12.009

Witkowski, J., Harwood, D.M. \& Kulikovskiy, M. (2012) Observations on Late Cretaceous marine diatom resting spore genera Pseudoaulicodiscus and Archaegoniothecium gen. nov. Nova Hedwigia, Beihefte 141: 375-404. 